PART III. OTHER

DZIAŁ III. INNE

\title{
POLISH ADAPTATION OF INTERPERSONAL SUPPORT EVALUATION LIST, A VERSION FOR STUDENTS (ISEL-48V.COLL.: INTERPERSONAL SUPPORT EVALUATION LIST, COLLEGE VERSION)
}

\section{POLSKA ADAPTACJA INTERPERSONALNEJ SKALI WSPARCIA SPOŁECZNEGO, WERSJA DLA STUDENTÓW (ISEL-48V.COLL.: INTERPERSONAL SUPPORT EVALUATION LIST, VERSION COLLEGE)}

\author{
Danuta Zarzycka $^{1(\mathrm{~A}, \mathrm{~B}, \mathrm{C}, \mathrm{D}, \mathrm{E}, \mathrm{F}, \mathrm{G})}$, Barbara Ślusarska ${ }^{2(\mathrm{C}, \mathrm{D}, \mathrm{F})}$, Danuta $^{\mathrm{Dy}} \mathrm{k}^{3(\mathrm{E})}$, \\ Anna Bednarek $^{1(\mathrm{~F})}$, Alina Trojanowska ${ }^{1(\mathrm{E})}$ \\ ${ }^{1}$ Department of Paediatric Nursing, Faculty of Health Sciences, Medical University of Lublin, Poland \\ ${ }^{2}$ Department of Family Medicine and Community Nursing, Chair of Oncology and Environmental Health, \\ Faculty of Health Sciences, Medical University of Lublin, Poland \\ ${ }^{3}$ Department of Anaesthesiology and Intensive Care Nursing, Chair of Nursing, \\ Poznan University of Medical Sciences, Poland
}

Authors' contribution Wkład autorów: A. Study design/planning zaplanowanie badań B. Data collection/entry zebranie danych C. Data analysis/statistics dane - analiza i statystyki D. Data interpretation interpretacja danych E. Preparation of manuscript przygotowanie artykułu F. Literature analysis/search wyszukiwanie i analiza literatury G. Funds collection zebranie funduszy

\section{Summary}

Background. The objective of the study was the adaptation and evaluation of the psychometric properties of the Interpersonal Social Support Scale version for students (ISEL-48v.Coll.: Interpersonal Support Evaluation List College Version).

Material and methods. The validation of the instrument was performed according to methodological standards, and statistical validation covered the assessment of criterion and construct validity, and reliability of the scale. The study was conducted with the use of the test-retest method, and a package of research instruments was applied, including, apart from the ISEL-48v.Coll., the PSS-14, HADS and SOC-29. The validation sample covered a group of 167 nursing students for the test and 115 for the retest.

Results. Reliability of the ISEL-48 v. Coll. as evaluated by Cronbach's alpha was 0.88 , and for the subscales, it ranged from 0.82 to 0.69 . The stability of results determined by the correlation in test-retest analysis ranged within $0.76-0.61(\mathrm{p}<0.001$ and $p<0.01)$.

Conclusions. The analysis of results shows that the adopted ISEL-48v.Coll. is an instrument possessing satisfying psychometric properties.

Keywords: scale adaptation, social support, Interpersonal Support Evaluation List, version for students

\section{Streszczenie}

Wprowadzenie. Celem badań było przeprowadzenie procedury adaptacji i oceny właściwości psychometrycznych Interpersonalnej Skali Wsparcia Społecznego w wersji dla studentów (ISEL-48v.Coll.: Interpersonal Support Evaluation List College version).

Materiał i metody. Adaptacja lingwistyczna skali została przeprowadzona zgodnie z obowiązującymi standardami metodologicznymi, a walidacja statystyczna poprzez określenie trafności kryterialnej, teoretycznej i rzetelności. W badaniu wykorzystano metodę test-retest i zastosowano pakiet narzędzi badawczych oprócz ISEL-48v.Coll. również PSS-14, HADS, SOC-29. Próba walidacyjna obejmowała grupę 167 studentów dla testu i 115 dla retestu.

Wyniki. Rzetelność ISEL-48 v.Coll. oceniana współczynnikiem alfa Cronbacha wynosiła 0.88 a dla podskal waha się od 0.82 do 0.69. Stałość wyników określona współczynnikiem korelacji w badaniu test-retest przyjmowała wartości od 0.76 do $0.61(\mathrm{p}<0.001$ and $\mathrm{p}<0.01)$. Wnioski. Analiza wyników wskazuje iż zaadaptowana ISEL-48v.Coll jest narzędziem o zadowalających właściwościach psychometrycznych.

Słowa kluczowe: adaptacja skali, wsparcie społeczne, Interpersonalna Skala Wsparcia

\footnotetext{
Społecznego, wersja dla studentów
}

\section{Figures: 0}

References: 19

Submitted: 2017 Nov 14

Accepted: 2017 Nov 15

Zarzycka D, Ślusarska B, Dyk D, Bednarek A, Trojanowska A. Polish adaptation of Interpersonal Support Evaluation List, a version for students (ISEL-48v.Coll.: Interpersonal Support Evaluation List, College Version). Health Prob Civil. 2017; 11(3): 280-286. DOI: https://doi.org/10.5114/hpc.2017.71889.

\footnotetext{
Address for correspondence / Adres korespondencyjny: Barbara Ślusarska, Department of Family Medicine and Community Nursing, Chair of Oncology and Environmental Health, Faculty of Health Sciences, Medical University of Lublin, Poland, Staszica street 4/219, 20-081 Lublin, Poland, e-mail: basia.slusarska@gmail. com, phone: +48814486810

Copyright: (C) 2017 Pope John Paul II State School of Higher Education in Biała Podlaska, Danuta Zarzycka, Barbara Ślusarska, Danuta Dyk, Anna Bednarek, Alina Trojanowska. This is an Open Access journal, all articles are distributed under the terms of the Creative Commons Attribution-NonCommercial-ShareAlike 4.0 International (CC BY-NC-SA 4.0) License (http://creativecommons.org/licenses/by-nc-sa/4.0/), allowing third parties to copy and redistribute the material in any medium or format and to remix, transform, and build upon the material, provided the original work is properly cited and states its license.
} 


\section{Introduction}

Studies on students in the eastern part of Europe including Poland show that they are upset, indicate low social support and have a weak sense of outer-containment. These features distinguish the group from the population of students in Western Europe [1,2,3,4,5,6,7].

The objective of the following research is to present the results of the adaptation procedure and the assessment of primary psychometric properties of ISEL-48v.Coll.: Interpersonal Support Evaluation List, College Version, by evaluating the reliability (internal compliance, absolute consistency) and validity (criteria).

\section{Social support - theoretical assumptions ISEL-48 v.Coll.}

The theoretical assumption determining social support and underpinning the development of ISEL-48 v.Coll. indicates a moderating role of social support in stressful events and depression symptoms as well as physical health disorders. While developing the questionnaire, the team of authors of the Interpersonal Support Evaluation List, College Version, concentrated on measuring social and appraisal support by examining

- self-esteem support

- belonging support

- tangible support $[8,9,10,11]$.

On formulating the assumptions of appraisal support, Cohen (1983) referred to the opinions of Lazarus, who suggests two most crucial aspects in the occurrence of stress reaction. They include the original assessment of the stressor (the cognitive aspect) and relating it to available resources of coping (the assessing element). In the both listed areas, the appraisal support is treated as the external resource which has an impact on the student who gets to know the stressor and assesses how it might be dealt with. Social support helps people to redefine the situation as less stressful although it is also burdened with the social assessment. The other limit to the appraisal support is the comparison of experiences and social values represented by supporters to the persons whom they support [12].

Self-esteem support has a positive impact on the person's comfort as it helps to assess potential stressors and emotional mechanisms that find their source in personal situational judgments and related feelings. At the same time, people with a low level of self-esteem support show a lack of control over events of the surrounding reality (personal helplessness) and a conviction of paucity of competencies to control stressful life events (universal helplessness) [12].

Belonging support causes an increase in resistance to a stressor thanks to the mechanism of relationship with the group, which has an overall positive impact on one's mood and health. The model assumes that there is an optimal level of belonging sense that determines health and welfare and, in case of health deterioration, belonging support may increase individual assessment with a positive health effect. As a result, in the case an individual has no opportunity to satisfy the needs (e.g. biological - nutrition), stress is perceptible. However, it can be decreased by belonging support and sense of solidarity with others (members of a support net) [12]. Tangible support refers to situations when the balance in social and economic dimensions is disturbed because of sudden fortuitous events, disease, the process of ageing or loss of income. The literature knows several research cases whose results presented the factors determining the impact of tangible support and its significance in aiding individuals in the case of natural disasters. In mass events, financial help or assistance in healthcare and other essential things such as medicines, drinking water or shelter are adequate, but the recipient of the support must be considered in terms of the extent of the aid. Financial support received by the persons in need may contribute to more a favourable assessment of one' own difficult situation [12].

\section{Characteristics of Interpersonal Support Evaluation List, College Version - ISEL-48v.Coll.}

The tool ISEL-48v.Coll. was published in 1984 by Sheldon Cohen and Harry M. Hoberman [12]. ISEL-48v. Coll. is the extension of 40- item tool ISEL-40 v. GP designed for the total population [13-15].

The Polish scale version, constructed after receiving the permission of its author (S. Cohen), is a four-level scale. The respondents could assess each statement in the following categories: False - 0; Probably false - 1; Probably true - 2; True - 3.

To obtain reliable results, half of the questions were negative in content, which requires recording data while calculating the value of social support; that is the sum of values of the scale positions. The total result of the scale ranges from 0 to 144; if the numerical value is bigger, it indicates that the respondents perceive greater accessibility of social support. The questionnaire can be used both in individual and group research. The time needed for answering the questions is between 5 and 8 minutes. 


\section{Material and methods}

\section{Adaptation and validation procedure ISEL-48 v. Coll.}

In the first stage of the procedure, the tool was translated into the Polish language by a person knowing English perfectly.

After developing a culturally appropriate tool's version, some further changes were made during the linguistic consultation process. The changes were of idiomatic character and served to improve the communication in the way statements are recorded on the scale.

The next stage was to perform a reverse translation, i.e. the tool translated into Polish was brought back into English by another qualified translator, and both versions were compared.

The project used such research tools as ISEL-48v.Coll, HADS, PSS-14; SOC-29, which allow assessing the reliability of the scale using the method of test-retest. The criterion validity and consistency of the scale were tested as well [16].

The Bioethical Commission functioning in the Lublin Medical University issued a positive opinion on the adaptive and validation/ ng procedure ISEL-48v.Coll. and gave it number KE-0254/7/2009.

The participation in the research was voluntary and anonymous, and the results were available online on individual profiles with reserved access on the website www.badania.umlub.pl after logging in with a unique number (login).

The statistical analysis was conducted with Statistica 9.0 PL programme, an advanced version for Windows.

\section{Characteristics of the validating sample}

The validating studies of Scale ISEL - 48v.Coll. were conducted in 2012 among students of the first year undergraduate nursing studies in the Medical University of Lublin. The research concerned estimating the reliability of the technique called test-retest and involved two stages. The first phase was performed on $9^{\text {th }}$ October 2012 in a group of 167 students. The other one was conducted 4 weeks later, i.e. on $6^{\text {th }}$ November 2012 , but this time the answers were provided by 115 students.

The mean age of the respondents both in the first and the other group was slightly above 19 years (19.22 19.30), with standard deviation $\pm 0,98$, which indicates that variation within the groups was moderate.

\section{Results}

The overall values of perceived social support in the respondents ranged from 24 to 144, within the scale values of $0-144$. The most obvious social support in students was visible in relation to the material dimension as it is commonly considered as the most tangible and quickest to achieve.

Because of increasing the number of levels from two to four in each of the scale positions, the results cannot be compared to the original scale ISEL - 48v.Coll. The most considerable variation in the results was obtained in the area of appraisal support and belonging support (SD: 7.02 and 6.74) (Table 1).

Table 1. Descriptive statistics, test statistics of the Polish version of scale ISEL-48v.Coll. for N=167

\begin{tabular}{|c|c|c|c|c|c|c|c|}
\hline Scale ISEL & Positions & Average & $\begin{array}{c}\text { Standard } \\
\text { deviation }\end{array}$ & Min. & Max. & Bias & Curtosis \\
\hline T-ISEL-v.12 Coll. & 12 & 35.58 & 4.49 & 4.00 & 36.0 & -0.64 & 0.03 \\
\hline B-ISEL-v.12 Coll. & 12 & 33.18 & 6.74 & 3.00 & 36.0 & -0.33 & -0.52 \\
\hline A-ISEL-v.12 Coll. & 12 & 35.16 & 7.02 & 3.00 & 36.0 & -0.88 & 0.51 \\
\hline S-ISEL-v.12 Coll & 12 & 30.41 & 5.02 & 4.00 & 34.0 & -0.21 & -0.48 \\
\hline ISEL-48v .Coll. & 48 & 140.28 & 18.57 & 24.00 & 144.0 & -0.59 & 0.42 \\
\hline
\end{tabular}

Abbreviations:

ISEL-48v. Coll. - availability of social support for students; range: 0-144

T-ISEL-12v. Coll.- availability of tangible social support for students; range: 0-36

A-ISEL-12v. Coll.- availability of appraisal social support for students; range: 0-36

B-ISEL-12v. Coll.- availability of belonging social support for students; range: 0-36

S-ISEL-12v. Coll.- availability of self-esteem social support for students; range: 0-36

To assess the reliability of the test-retest method, the authors repeated the study after a four-week interval. The results showed a satisfying stability of how the availability of social support was perceived by the students. The stability coefficient for the scale was 0.76 and for the particular subscales ranged from 0.61 (S-ISEL-12v.Coll.) to 0.72 (A-ISEL-12v.Coll.). It must be noticed that the analysis of the Polish version of ISEL-48v.Coll. indicates the 
highest stability for the total result of the scale. In the psychometric validation of the original version of the scale ISEL - 48v.Coll., the coefficient of the results stability was not used (Table 2.).

Table 2. Analysis of reliability of subscales - T-ISEL-12v.Coll., B-ISEL-12v.Coll., A-ISEL-12v.Coll., S-ISEL-12v.Coll.

\begin{tabular}{|c|c|c|c|c|c|c|}
\hline No. & $\begin{array}{l}\text { Scale position } \\
\text { T-ISEL-12v. Coll.- }\end{array}$ & $\begin{array}{c}\text { Scale average } \\
\text { after deleting } \\
\text { positions } \\
\end{array}$ & $\begin{array}{c}\text { Scale variance } \\
\text { after deleting } \\
\text { positions }\end{array}$ & $\begin{array}{l}\text { Correlation of } \\
\text { position with } \\
\text { scale } \\
\end{array}$ & $\begin{array}{l}\text { Squared mul- } \\
\text { tiple correla- } \\
\text { tion }\end{array}$ & $\begin{array}{l}\text { Cronbach's al- } \\
\text { pha after delet- } \\
\text { ing positions }\end{array}$ \\
\hline 1. & T-ISEL-12v.Coll. 1 & 34.92 & 28.39 & 0.36 & 0.29 & 0.70 \\
\hline 2. & T-ISEL-12v.Coll. 10 & 35.16 & 26.58 & 0.40 & 0.38 & 0.69 \\
\hline 3. & T-ISEL-12v.Coll. 11 & 35.15 & 26.54 & 0.39 & 0.31 & 0.69 \\
\hline 4. & T-ISEL-12v.Coll. 18 & 34.60 & 30.55 & 0.18 & 0.47 & 0.72 \\
\hline 5. & T-ISEL-12v.Coll. 19 & 34.84 & 29.80 & 0.20 & 0.42 & 0.71 \\
\hline 6. & T-ISEL-12v.Coll. 2 & 35.28 & 27.96 & 0.28 & 0.32 & 0.70 \\
\hline 7. & T-ISEL-12v.Coll. 29 & 34.87 & 28.40 & 0.34 & 0.33 & 0.70 \\
\hline 8. & T-ISEL-12v.Coll. 30 & 35.41 & 27.02 & 0.31 & 0.17 & 0.70 \\
\hline 9. & T-ISEL-12v.Coll. 31 & 35.25 & 26.13 & 0.50 & 0.44 & 0.67 \\
\hline 10. & T-ISEL-12v.Coll. 35 & 35.14 & 27.95 & 0.30 & 0.21 & 0.70 \\
\hline 11. & T-ISEL-12v.Coll. 36 & 35.18 & 25.71 & 0.40 & 0.29 & 0.69 \\
\hline 12. & T-ISEL-12v.Coll. 44 & 35.00 & 24.79 & 0.50 & 0.36 & 0.67 \\
\hline No. & $\begin{array}{l}\text { Scale position } \\
\text { B-ISEL-12v. Coll }\end{array}$ & $\begin{array}{c}\text { Scale average } \\
\text { after deleting } \\
\text { positions } \\
\end{array}$ & $\begin{array}{c}\text { Scale variance } \\
\text { after deleting } \\
\text { positions }\end{array}$ & $\begin{array}{l}\text { Correlation of } \\
\text { position with } \\
\text { scale } \\
\end{array}$ & $\begin{array}{l}\text { Squared mul- } \\
\text { tiple correla- } \\
\text { tion } \\
\end{array}$ & $\begin{array}{l}\text { Cronbach's al- } \\
\text { pha after delet- } \\
\text { ing positions }\end{array}$ \\
\hline 1. & B-ISEL-12v.Coll. 12 & 30.73 & 39.60 & 0.43 & 0.23 & 0.72 \\
\hline 2. & B-ISEL-12v.Coll. 3 & 32.51 & 39.63 & 0.31 & 0.14 & 0.74 \\
\hline 3. & B-ISEL-12v.Coll. 8 & 31.16 & 38.23 & 0.42 & 0.27 & 0.72 \\
\hline 4. & B-ISEL-12v.Coll. 9 & 31.93 & 39.66 & 0.18 & 0.07 & 0.76 \\
\hline 5. & B-ISEL-12v.Coll. 20 & 31.20 & 38.00 & 0.44 & 0.24 & 0.72 \\
\hline 6. & B-ISEL-12v.Coll. 24 & 31.00 & 41.19 & 0.19 & 0.11 & 0.75 \\
\hline 7. & B-ISEL-12v.Coll. 28 & 30.68 & 43.62 & 0.03 & 0.09 & 0.76 \\
\hline 8. & B-ISEL-12v.Coll. 32 & 31.20 & 37.83 & 0.48 & 0.37 & 0.72 \\
\hline 9. & B-ISEL-12v.Coll. 37 & 31.04 & 38.45 & 0.40 & 0.22 & 0.73 \\
\hline 10. & B-ISEL-12v.Coll. 40 & 31.67 & 34.90 & 0.56 & 0.36 & 0.70 \\
\hline 11. & B-ISEL-12v.Coll. 45 & 31.89 & 34.84 & 0.60 & 0.40 & 0.70 \\
\hline 12. & B-ISEL-12v.Coll. 46 & 31.24 & 36.66 & 0.61 & 0.45 & 0.70 \\
\hline No. & $\begin{array}{l}\text { Scale position } \\
\text { A-ISEL-12v. Coll.- }\end{array}$ & $\begin{array}{c}\text { Scale average } \\
\text { after deleting } \\
\text { positions } \\
\end{array}$ & $\begin{array}{c}\text { Scale variance } \\
\text { after deleting } \\
\text { positions }\end{array}$ & $\begin{array}{c}\text { Correlation of } \\
\text { position with } \\
\text { scale } \\
\end{array}$ & $\begin{array}{l}\text { Squared mul- } \\
\text { tiple correla- } \\
\text { tion } \\
\end{array}$ & $\begin{array}{l}\text { Cronbach's } \\
\text { alpha after de- } \\
\text { leting positions }\end{array}$ \\
\hline 1. & A-ISEL-12v.Coll. 7 & 33.77 & 43.39 & 0.57 & 0.48 & 0.80 \\
\hline 2. & A-ISEL-12v.Coll. 13 & 35.01 & 39.99 & 0.51 & 0.49 & 0.80 \\
\hline 3. & A-ISEL-12v.Coll. 14 & 34.30 & 41.02 & 0.54 & 0.43 & 0.80 \\
\hline 4. & A-ISEL-12v.Coll. 16 & 34.02 & 41.70 & 0.51 & 0.32 & 0.80 \\
\hline 5. & A-ISEL-12v.Coll. 21 & 34.77 & 40.94 & 0.45 & 0.35 & 0.81 \\
\hline 6. & A-ISEL-12v.Coll. 23 & 35.09 & 41.97 & 0.35 & 0.27 & 0.82 \\
\hline 7. & A-ISEL-12v.Coll. 25 & 33.99 & 42.20 & 0.54 & 0.44 & 0.80 \\
\hline 8. & A-ISEL-12v.Coll. 27 & 34.72 & 43.42 & 0.29 & 0.16 & 0.82 \\
\hline 9. & A-ISEL-12v.Coll. 33 & 34.11 & 42.82 & 0.44 & 0.35 & 0.81 \\
\hline 10. & A-ISEL-12v.Coll. 39 & 34.16 & 41.41 & 0.55 & 0.47 & 0.80 \\
\hline 11. & A-ISEL-12v.Coll. 4 & 33.65 & 44.81 & 0.48 & 0.40 & 0.80 \\
\hline 12. & A-ISEL-12v.Coll. 41 & 34.01 & 41.42 & 0.63 & 0.53 & 0.79 \\
\hline No. & $\begin{array}{l}\text { Scale position } \\
\text { S-ISEL-12v. Coll.- }\end{array}$ & $\begin{array}{c}\text { Scale average } \\
\text { after deleting } \\
\text { positions } \\
\end{array}$ & $\begin{array}{c}\text { Scale variance } \\
\text { after deleting } \\
\text { positions }\end{array}$ & 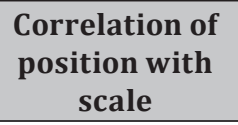 & $\begin{array}{l}\text { Squared mul- } \\
\text { tiple correla- } \\
\text { tion } \\
\end{array}$ & $\begin{array}{l}\text { Cronbach's al- } \\
\text { pha after delet- } \\
\text { ing positions }\end{array}$ \\
\hline 1. & S-ISEL-12v.Coll. 5 & 27.61 & 23.97 & 0.14 & 0.16 & 0.69 \\
\hline 2. & S-ISEL-12v.Coll. 15 & 29.31 & 24.60 & -0.03 & 0.16 & 0.72 \\
\hline
\end{tabular}




\begin{tabular}{|c|c|c|c|c|c|c|}
\hline 3. & S-ISEL-12v.Coll. 17 & 28.49 & 18.76 & 0.56 & 0.38 & 0.62 \\
\hline 4. & S-ISEL-12v.Coll. 22 & 29.36 & 24.56 & -0.02 & 0.07 & 0.71 \\
\hline 5. & S-ISEL-12v.Coll. 26 & 28.72 & 22.35 & 0.24 & 0.14 & 0.68 \\
\hline 6. & S-ISEL-12v.Coll. 34 & 27.92 & 21.73 & 0.35 & 0.19 & 0.66 \\
\hline 7. & S-ISEL-12v.Coll. 38 & 28.72 & 19.96 & 0.50 & 0.42 & 0.64 \\
\hline 8. & S-ISEL-12v.Coll. 42 & 28.35 & 19.78 & 0.52 & 0.43 & 0.64 \\
\hline 9. & S-ISEL-12v.Coll. 43 & 28.28 & 20.44 & 0.36 & 0.34 & 0.66 \\
\hline 10. & S-ISEL-12v.Coll. 47 & 28.63 & 20.58 & 0.33 & 0.17 & 0.67 \\
\hline 11. & S-ISEL-12v.Coll. 48 & 28.41 & 18.51 & 0.62 & 0.53 & 0.61 \\
\hline 12. & S-ISEL-12v.Coll. 6 & 27.89 & 23.60 & 0.17 & 0.15 & 0.69 \\
\hline
\end{tabular}

Abbreviations:

T-ISEL-12v. Coll.- availability of tangible social support for students

B-ISEL-12v. Coll.- availability of belonging social support for students

A-ISEL-12v. Coll.- availability of appraisal social support for students

S-ISEL-12v. Coll.- availability of self-esteem social support for students

The analysis of the questionnaire positions conducted with the assumption that the four factors must be isolated resulted in $36.12 \%$ of common variation.

\section{Criterion validity}

The overall result for the scale ISEL-48v.Coll. reflecting how social support availability is perceived correlates with each of the criteria on the statistically significant level. However, it shows the highest negative correlation with depression ( $r=-0.49 ; \mathrm{p}<0.001)$, and positive correlation with the sense of resourcefulness (a component of life orientation) $(\mathrm{r}=0.43 ; \mathrm{p}<0.001)$. The criterion validity of the original version of ISEL-48v.Coll. was presented on the basis of positive correlation with the criterion of supportive social behaviours $(r=0.46, p<0.001)$ and negative correlation with anxiety $(\mathrm{r}=-0.52$ and $\mathrm{r}=-0.64, \mathrm{p}<0.01)$.

Cohen's studies also concerned determining the criterion validity of the scale ISEL-48v.Coll. through the correlation of social support with depression. The results, as expected, indicate a negative correlation $(\mathrm{r}=-0.22$ and $\mathrm{r}=-0.47, \mathrm{p}<0.05)[11]$ (Table 3).

Table 3. Correlations ( $\mathrm{r}$ - coefficient of Spearman's range correlation) between the total score of ISEL-48v.Coll., total scores of subscales and anxiety, depression, stress and life orientation.

\begin{tabular}{|c|c|c|c|c|c|c|}
\hline Scale & PSS- stress & HADS-anxiety & $\begin{array}{c}\text { HADS-de- } \\
\text { pression }\end{array}$ & $\begin{array}{c}\text { SOC-sense } \\
\text { of intelligibil- } \\
\text { ity }\end{array}$ & $\begin{array}{c}\text { SOC-sense } \\
\text { of resource- } \\
\text { fulness }\end{array}$ & $\begin{array}{c}\text { SOC- sense } \\
\text { of meaning- } \\
\text { fulness }\end{array}$ \\
\hline ISEL-48v.Coll. & $-0.45^{*}$ & $-0.33^{*}$ & $-0.49^{*}$ & $0.31^{*}$ & $0.43^{*}$ & $0.40^{*}$ \\
\hline T-ISEL-12v.Coll. & $-0.33^{*}$ & $-0.025^{*}$ & $-0.33^{*}$ & $0.18^{*}$ & $0.28^{*}$ & $0.26^{*}$ \\
\hline A-ISEL-12v.Coll. & $-0.27^{*}$ & $-0.23^{*}$ & $-0.38^{*}$ & $0.20^{*}$ & $0.25^{*}$ & $0.23^{*}$ \\
\hline B-ISEL-12v.Coll. & $-0.37^{*}$ & $-0.26^{*}$ & $-0.41^{*}$ & $0.26^{*}$ & $0.36^{*}$ & $0.36^{*}$ \\
\hline S-ISEL-12v.Coll. & $-0.51^{*}$ & $-0.32^{*}$ & $-0.44^{*}$ & $0.34^{*}$ & $0.50^{*}$ & $0.44^{*}$ \\
\hline
\end{tabular}

* $\mathrm{p}<0,05$

Abbreviations:

ISEL-48v. Coll. - availability of social support for students

T-ISEL-12v. Coll.- availability of tangible social support for students

A-ISEL-12v. Coll.- availability of appraisal social support for students

B-ISEL-12v. Coll.- availability of belonging social support for students

S-ISEL-12v. Coll.- availability of self-esteem social support for students

\section{Discussion}

The procedure of defining psychometric characteristics of the scale ISEL-48v.Coll. by its author, S. Cohen, was presented together with the presentation of the authors' results of the study. The research sample assessing the reliability of the test-retest method was dominated by women, which is not representative of the student population. At the same time, however, S. Cohen conducted an assessment of psychometric characteristics of the scale ISEL-v.Coll. on the sample of 70 students from the University of Oregon, where again women were in the majority $[8,12]$. 
The coefficients of correlation between the overall result of the scale and the results of the subscales ranging between 0.75 to 0.83 were obtained in the Greek adaptation of ISEL-48v.Coll. This also indicates a better internal-consistency of the tool with regard to the characteristics presented by the author of the scale and it is comparable with the results achieved in the Polish version of the tool [17].

The scale was also evaluated for its validity and reliability by other researchers. E. Dalistamati et al. [17] published the Greek dichotomous version of ISEL - 48v.Coll., and their results can be recognised as comparable to the version presented in the above research. The Cronbach's alpha reliability coefficient for the whole scale amounted to 0.89 , with the stability in the test-retest method of 0.67 ; the lowest coefficient characterising the subscale S-ISEL-12v.Coll. was 0.45, and for T-ISEL-12v.Coll. - 0.63 [17]. More satisfying values for Cronbach's alpha were shown for A-ISEL-12v.Coll. - 0,75 and B-ISEL-12v.Coll. - 0.84, which confirms the trend of Cronbach's alpha coefficient in the Polish adaptation of the tool by D. Zarzycka. The criterion validity assessed by the correlation of the overall results and subscales in relation to anxiety, depression and life events, indicates the statistically significant correlations on the level $\mathrm{p}<0.001$, which is convergent with the correlation's results achieved in the presented project [14].

On the other hand, Brookings and Bolton [18] did a confirmatory factor analysis confirming the usefulness of the scale ISEL-48v.Coll. in assessing social support availability, which fits the four-factor data, i.e. subscales. The indicator RMSEA for the factor models ranged from 0.05 to 0.07 , which shows quite a fine fitting to the empirical data [18]. High correlations between subscales could suggest the possibility of using the one-dimensional scale, which is recommended by other researchers [19]. However, on such occasion, the loss of unique appraisinglyvaluing information, wherein the smallest or thogonal subscales are the carriers, must be assumed. Therefore, the recommendation to use the overall result of ISEL-48v.Coll. together with the subscales results was formulated.

\section{Conclusions}

1. The Scale ISEL-48v.Coll. has satisfying reliability indicators both for the subscales and the complete tool. Hence, the tool should be used in empirical studies.

2. The stability of the results assessed in a 4-week interval was satisfying.

3. The criterion validity of the tool is consistent with the accepted standards in other validating studies.

\section{Acknowledgements}

The authors would like to thank professor Sheldon Cohen from the Laboratory for the Study of Stress, Immunity and Disease, Department of Psychology, Carnegie Mellon University, Pittsburgh for granting permission to adapt ISEL-48v.Coll. and kind expressing opinions on this procedure.

This study was funded by the MS\&HE (Ministry of Science and Higher Education), grant No. 404 153834. All procedures performed in studies involving human participants were in accordance with the ethical standards of the institutional and/or national research committee (a positive opinion of Bioethical Commission functioning by the Lublin Medical University and it was marked with KE-0254/7/2009 number) and with the 1964 Declaration of Helsinki and its later amendments or comparable ethical standards. This article does not concern any studies on animals performed by any of the authors. Informed consent was obtained from all individual participants involved in the study.

\section{References:}

1. De Girolamo G, Dagani J, Signorini G. Youth mental health from continuity of psychopathology to continuity of care. Word Child \& Adolescent. Psychiatry 2014; 6: 6-8.

2. Mikolajczyk RT, Maxwell AE, Naydenova V, Meier S, Ansari WE. Depressive symptoms and perceived burdens related to being a students: Survey in three European countries. Clin Pract Epidemiol Ment Health. 2008; 19: doi:10.1186/1745-0179-4-19.

3. Jané-Llopis E, Anderson P. Mental Health Promotion and Mental Disorder Prevention. A Policy for Europe. Nijmegen: Radboud University Nijmegen, 2005.

4. Wardle J, Steptoe A, Gulis G, Sartory G, Sęk H, Todorova I, Vogele C, Ziarko M. Depression, perceived control, and life satisfaction in university students from Central Eastern and Western Europe. Int J Behav Med 2004; 11: 27-36.

5. Steptoe A, Wardle J. Health behavior, risk awareness and emotional well-being in students from Eastern Europe and Western Europe. Soc Sci Med 2001; 53: 1621-1630. 
6. Wilks SE, Spivey CA. Resilience in undergraduate social work students: Social support and adjustment to academic stress. Soc Work Educ 2010; 29:276-288.

7. Sęk H. Chosen issues of social support. In: Sęk H., editor. Clinical psychology. [Polish]. Warsaw: PWN; 2005. p. 252-255.

8. Cohen S. Mermelstein R, Kamarck T, Hoberman HM. Measuring the Functional Components of Social Support. In: Social Support: Theory, Research and Applications. Martinus Nijhoff Publishers. Dordrecht, Boston, Lancaster: 1985. p. 73-94.

9. Cohen S. Pressman S. Stress - buffering hypothesis. In: Anderson NB., editor. Encyclopedia of Health \&Behavior. Sage Publications. APA. 2004; pp. 780-782.

10. Cohen S, McKay G. Social Support, Stress and the Buffering Hypothesis: A Theoretical Analysis. In: Baum A, Taylor SE, Singer JE., editors. Handbook of Psychology and Health. Hillsdale. NJ. 1984. p. 255-260.

11. Cobb S. Social support as a moderator of life stress. Psychosom Med. 1976; 38: 300-314.

12. Cohen S, Hoberman HM. Positive events and social support as buffers of life change stress. J Appl Sociol Psychol. 1983; 13: 99-125.

13. Cohen`s Scales. [cited 2016 Jul 01]. Available from: http://www.psy.cmu.edu/ scohen/\&ei

14. Zarzycka D, Śpila B, Wrońska I, Makara-Studzińska M. Validation analysis of chosen aspects of Interpersonal Support Evaluation List - 40 v. General Population (ISEL-40 v.GP). [Polish] Psychiatry 2010; 7: 83-94.

15. Szlachta E. The attempt of adaptation and validation of Polish version of The Interpersonal Support Evaluation List (ISEL). [Polish] Psychol Rev 2009; 52: 433-451.

16. Brzeziński Z. Validity and Reliability of Psychological Tests. Selection of Texts. Psychology Publishing, Gdańsk 2005.

17. Dalistamati E, Samacouri M, Davis E. Vorvolacos T, Xenitidis K, Livaditis M. Interpersonal Support Evaluation List (ISEL) - College Version: validation and application in Greek sample. Int J Soc Psychol 2006; 52: 552-560.

18. Brookings JB, Bolton B. Confirmatory Factor Analysis of the Interpersonal Support Evaluation List. Am J Commun Psychol 1988; 16: 137-147.

19. Bauman EM, Haaga DAF, Kaltman S, Dutton MA. Measuring social support in battered women: Factor structure of the Interpersonal Support Evaluation List (ISEL). Violence Against Wom. 2012; 18 (1): $30-43$. 